\title{
Grain Sorghum Response to Hybrid, Row Spacing, and Plant Populations along the Upper Texas Gulf Coast
}

\author{
Dan D. Fromme, ${ }^{1}$ Carlos J. Fernandez, ${ }^{2}$ W. James Grichar, ${ }^{3}$ and Rick L. Jahn ${ }^{4}$ \\ ${ }^{1}$ Texas AgriLife Extension Service, Corpus Christi, TX 78406, USA \\ ${ }^{2}$ Texas AgriLife Research, Corpus Christi, TX 78406, USA \\ ${ }^{3}$ Texas AgriLife Research, Corpus Christi, TX 78102, USA \\ ${ }^{4}$ Texas AgriLife Extension Service, Wharton, TX 77488, USA \\ Correspondence should be addressed to Dan D. Fromme, d-fromme@tamu.edu
}

Received 27 April 2012; Revised 13 June 2012; Accepted 14 June 2012

Academic Editor: David Clay

Copyright () 2012 Dan D. Fromme et al. This is an open access article distributed under the Creative Commons Attribution License, which permits unrestricted use, distribution, and reproduction in any medium, provided the original work is properly cited.

Grain sorghum (Sorghum bicolor L. Moench) along the upper Texas Gulf Coast is planted at different row spacings, plant populations, and hybrids according to grower preference and location. This study was conducted over a 3-year period (2001 to 2003) to determine the combination of hybrid, row spacing, and plant population on yield and net return per hectare. Below average rainfall for May and June occurred in 2002 and 2003 which resulted in lower yields than 2001. In 2001 and 2003, Dekalb (DK) 54 generally produced higher yields than Asgrow (A) 571 on the $51 \mathrm{~cm}$ row spacing. In 2002, no differences in grain sorghum yield were found when comparing both hybrids, plant populations, or row spacing with the exception of A 571 planted at 148,000 plants/ha on $102 \mathrm{~cm}$ centers which resulted in a yield reduction of at least $25 \%$. When net returns were compared regardless of year or rainfall received, net dollar value per hectare tended to be higher for the $51 \mathrm{~cm}$ row spacing, especially with A 571 .

\section{Introduction}

Hybrid selection, plant population, and row spacing are variables that can have a significant impact on the net returns of sorghum producers. Though optimal plant densities for grain sorghum differ from region to region, previous research has indicated that grain yields generally increase as plant populations increase [1-3]. At lower than suggested plant densities, grain sorghum head number per plant or seed number per head increased when compared to the recommended plant density [4-7]. In other crops, Grichar [8] reported variable results of the effects of different seeding rates in soybean (Glycine max L.). He reported that the effect of seeding rate on soybean yields varied from year to year depending on variety and rainfall received during the growing season. Brown et al. [9] showed a 34\% yield increase in corn (Zea mays L.) grown on $51 \mathrm{~cm}$ rows compared with $102 \mathrm{~cm}$ rows. Fulton [10] reported that under conditions of adequate soil moisture, higher corn plant densities (54,360 plants/ha) produced greater yields than lower densities $(39,540$ plants/ha), and rows spaced at $50 \mathrm{~cm}$ produced higher yields than rows spaced $100 \mathrm{~cm}$ apart.

The row spacing in a crop can also impact crop yield potential [3, 11-13]. Staggenborg et al. [3] reported that crop row spacings of less than $76 \mathrm{~cm}$ would increase grain yield in areas with high yield potential with little risk of reduced yield in areas with lower yield potential. Grichar [14] reported that soybeans in a twin-row configuration yielded more than the single-row system $50 \%$ of the time. Reducing the distance between rows can also improve weed control by increasing crop competitiveness and reducing light transmittance to the soil [15-17]. Johnson et al. [18] reported that total weed densities were less when peanut (Arachis hypogaea L.) rows were spaced $30 \mathrm{~cm}$ apart compared with rows spaced $91 \mathrm{~cm}$ apart. Teasdale [19] showed that reduced row spacing and increased corn populations decreased weed growth in the absence of herbicides and shortened the time of canopy closure by one week.

Seedlings in close proximity to each other express phytochrome-mediated responses by developing narrow leaves, 
long stems, and less massive roots [20]. Planting a crop in a pattern that reduces the spacing of plants within and between rows can increase plant biomass and leaf area index [21]. Work by Bullock et al. [21] showed that reduced row spacing increased the total interception of photosynthetic active radiation by the corn canopy and redistributed the radiation toward the top of the canopy.

Major grain sorghum production regions in Texas include the upper Gulf Coast region which produces $8 \%$ of the Texas' sorghum crop [22]. This area normally has high rainfall which allows for consistently significant sorghum yields [22]. Seeding rates can vary from region to region across Texas, but typically under dry condition the seeding rate is 49,000 to 74,000 seed/ha while under irrigation or higher moisture conditions seeding rates can be as high as $272,000 \mathrm{seed} / \mathrm{ha}$, depending on planting date [23]. Typically, seeding rates for producers along the upper Texas Gulf Coast vary from 124,000 to 247,000 seed/ha.

While the majority of grain sorghum is grown in rows with spacings ranging from 69 to $102 \mathrm{~cm}$, some sorghum is planted broadcast [22]. The majority of producers in this region plant on $102 \mathrm{~cm}$ row spacings. With the wide variation in seeding rate and row spacing, many producers question whether there is an optimum plant density for grain sorghum grown under different row spacings and whether this can lead to higher profits. Another frequently asked question is whether or not a specific hybrid is better adapted to the narrow row environment than others. For these reasons, the objectives of this study were to determine (a) the effect of grain sorghum hybrid, (b) plant density, and (c) row spacing on grain sorghum yield and net returns.

\section{Materials and Methods}

2.1. Research Sites. The three-year (2001 to 2003) field study was conducted in Wharton County $\left(29.12^{\circ} \mathrm{N}, 96.37^{\circ} \mathrm{W}\right)$ under conventional tillage system on the Richard Raun farm located near Louise, Texas. This field had previously been in rice (Oryza sativa L.) production for two years previous to grain sorghum production during the three-year period. The soils at this location were an Edna fine sandy loam (fine, smectitic, hyperthermic, Vertic Hapludalfs, $0.9 \%$ organic matter, $\mathrm{pH}$ 7.1). Each year the study was moved to different locations within the same field.

2.2. Planting Dates and Plot Layout. Grain sorghum was planted on March 21, 2001, March 27, 2002, and March 12 , 2003. Studies were conducted utilizing a randomized complete block design with a $2 \times 2 \times 3$ factorial treatment arrangement with 3 replicates. The three factors included two grain sorghum hybrids (Dekalb (DK 54), Asgrow (A 571)), two row spacings $(51,102 \mathrm{~cm}$ ), and three plant populations (148-160,000, 185-198,000, and 222-235,000/ha). Wholeplot treatments of sorghum hybrid were $12.7 \mathrm{~m}$ wide with row spacing and plant populations within each cultivar and $9.1 \mathrm{~m}$ in length. Fertilizer applied was based on the soil test recommendations provided by the Texas AgriLife Extension Service Soil and Plant Testing Laboratory. Fertilizer rates of $224 \mathrm{~kg} / \mathrm{ha}$ of $24-12-6$ were applied prior to planting
TABLE 1: Monthly rainfall at the study location from 2001 to 2003.

\begin{tabular}{lcccc}
\hline \multirow{2}{*}{ Month } & \multicolumn{4}{c}{ Monthly rainfall $(\mathrm{mm})$} \\
& 2001 & 2002 & 2003 & 20 yr average \\
\hline March & 88.9 & 33.0 & 45.7 & 80.8 \\
April & 17.8 & 86.4 & 20.3 & 83.8 \\
May & 182.9 & 55.9 & 2.5 & 119.3 \\
June & 58.4 & 83.8 & 73.7 & 126.5 \\
July & 20.3 & 396.2 & 332.7 & 83.1 \\
\hline Total & 368.3 & 655.3 & 474.9 & 493.5 \\
\hline
\end{tabular}

and lightly disked into the soil surface approximately 2 to 3 weeks prior to sorghum planting. All treatments were planted flat or without a raised seedbed. Grain sorghum was planted with a Monosem vacuum planter (Monosem ATI, Inc., 17135 West 116th Street, Leneka, KS 66219) equipped with precision seed meters calibrated to deliver the desired seeding rate. Plant counts taken 4 to $6 \mathrm{wk}$ after planting assured that each plot was within the desired plant populations. If any plots contained more than the desired plant populations, the excessive plants were hand-pulled from the plots. None of the plots contained less than the desired number of plants. S-metolachlor (Dual Magnum (Syngenta Crop Protection, Wilmington, DE 19810)) was applied preemergence at $2.3 \mathrm{~L} /$ ha for weed control.

2.3. Data Collection. Crop yield was determined by harvesting the four rows of the $51 \mathrm{~cm}$ plots, and the two rows of the $102 \mathrm{~cm}$ plots with a small plot combine, and crop weights were adjusted to $14 \%$ moisture. Seed costs and grain sorghum prices were calculated based on April, 2012 prices (L. Falconer, personal communication). Seed costs were calculated at $\$ 6.60 / \mathrm{kg}$ (imidacloprid treated) while grain sorghum price was based on $\$ 9.00 / 45.4 \mathrm{~kg}$. Net value per hectare was calculated by taking the yield/hectare, dividing by 45.4 , multiplying by $\$ 9.00$ then subtracting seed costs $(\$ 6.00,7.50,9.00$ for $148-160,000,185-198,000$, or $222-$ 235,000 seed/ha, resp.). Herbicide costs were figured constant across all row spacings and plant populations.

2.4. Data Analysis. Data were subjected to ANOVA and analyzed using PROC GLM with SAS (SAS Institute, Inc., Cary, NC) and a model statement appropriate for a factorial design with sorghum hybrid, seeding rate, and row spacing as random effects. Treatments means were separated by Fisher's protected least significant difference test at $P=0.05$. Data for the three years were analyzed separately due to year by treatment interactions for yield and net value.

\section{Results}

3.1. Rainfall. Rainfall amounts were variable for the three years (Table 1). Rainfall in 2001 can be characterized as below average for April, June, and July with above average rainfall for May [23]. In 2002, below average rainfall was received for March, May, and June while July received an abnormal amount of rainfall due to a hurricane which passed close to the area. Rainfall in 2003 was below normal for all months 
TABLE 2: Grain sorghum yield as influenced by hybrid, row spacing, and seeding rate.

\begin{tabular}{|c|c|c|c|c|c|}
\hline \multirow{2}{*}{ Hybrid } & \multirow{2}{*}{ Row spacing $(\mathrm{cm})$} & \multirow{2}{*}{ Plant population (1000's/ha) } & \multicolumn{3}{|c|}{ Yield response (kg/ha) } \\
\hline & & & 2001 & 2002 & 2003 \\
\hline \multirow{6}{*}{ Dekalb DK54 } & \multirow{3}{*}{51} & $148-160$ & 6686 & 3321 & 3070 \\
\hline & & $185-198$ & 7133 & 3770 & 3118 \\
\hline & & $222-235$ & 6106 & 3171 & 3313 \\
\hline & \multirow{3}{*}{102} & $148-160$ & 5715 & 3269 & 3775 \\
\hline & & $185-198$ & 6388 & 3420 & 2309 \\
\hline & & $222-235$ & 6308 & 3252 & 2859 \\
\hline \multirow{6}{*}{ Asgrow A571 } & \multirow{3}{*}{51} & $148-160$ & 5799 & 3114 & 3265 \\
\hline & & 185-198 & 6595 & 3877 & 2266 \\
\hline & & $222-235$ & 6336 & 3882 & 2607 \\
\hline & \multirow{3}{*}{102} & $148-160$ & 5196 & 1948 & 3079 \\
\hline & & $185-198$ & 5075 & 2913 & 2910 \\
\hline & & $222-235$ & 5173 & 2849 & 2578 \\
\hline $\operatorname{LSD}(0.05)$ & & & 1116 & 1316 & 773 \\
\hline
\end{tabular}

except July which again received above average rainfall due to a tropical system which passed through the area. The above normal rainfall for July in both 2002 and 2003 came too late to be of any help during the 2002 and 2003 growing season.

\subsection{Grain Sorghum Response to Hybrid, Row Spacing, and} Plant Populations. Since there was a grain sorghum hybrid by row spacing by plant population interaction for yield and net value in each year, data were not combined over years for statistical analysis.

In 2001, DK 54 planted on $51 \mathrm{~cm}$ centers at 185 to 198,000 plants/ha produced the greatest yield (Table 2). The DK 54 plantings on $51 \mathrm{~cm}$ centers at 148 to 160,000 or 222 to 235,000 plants/ha and the $102 \mathrm{~cm}$ center plantings at 185,000 plants/ha or greater produced yields that were not different from DK 54 on $51 \mathrm{~cm}$ centers planted at 185 to 198,000 plants/ha. For the A 571 plantings, only those planted on $51 \mathrm{~cm}$ centers at 185,000 plants/ha or greater produced yields that were not different from DK 54 planted on $51 \mathrm{~cm}$ centers at 185 to 198,000 plants/ha. When only A 571 plantings were compared, $51 \mathrm{~cm}$ center plantings at 185 to 198,000 plants/ha produced the greatest yield, and all $51 \mathrm{~cm}$ center plantings were not different; however, all $102 \mathrm{~cm}$ center plantings were less than the $51 \mathrm{~cm}$ centers plantings at 185 to 198,000 plants/ha.

In 2002, grain sorghum yields were similar for all hybrids, row spacings, and plant populations with the exception of the A 571 planted on $102 \mathrm{~cm}$ centers with a plant population of 148 to 160,000 plants/ha which produced less than $2000 \mathrm{~kg} / \mathrm{ha}$ (Table 2). None of the other row spacings or plant populations produced less than $2849 \mathrm{~kg} / \mathrm{ha}$.

In 2003, DK 54 planted on $102 \mathrm{~cm}$ centers with a plant population of 148 to 160,000 plants/ha produced the greatest yield (Table 2). All DK 54 plantings on $51 \mathrm{~cm}$ centers and A 571 planted on $51-$ and $102 \mathrm{~cm}$ centers at 148 to 160,000 plants/ha produced yields similar to DK 54 planted on $102 \mathrm{~cm}$ centers at 148 to 160,000 plants/ha. Grain sorghum yields were lower with all plantings with plant populations of $185,000 \mathrm{plant} / \mathrm{ha}$ or greater with the exception of DK 51 planted on $51 \mathrm{~cm}$ centers.

It has been reported that the yield response to narrow rows in corn and grain sorghum is affected by many environmental, spatial, and temporal field interactions $[1-3,10,16]$. It has also been suggested that a positive yield response to narrow rows is more likely to occur in the presence of environmental yield-limiting factors. Andrade et al. [17] reported that the narrow-row yield response was inversely proportional to the radiation interception achieved with wider rows. Under very favorable growing conditions, when radiation interception for wide rows was optimized, the yield response to narrowing the rows was minimized.

In 2001, the high rainfall for May (Table 1) boosted grain sorghum yield and resulted in higher yields from the narrow row plantings (Table 2). The rainfall events during May were approximately 50 to 70 days after grain sorghum planting and this is the period when the reproductive structures of the panicle form and the maximum number of seeds per panicle is set [22]. During this period, grain sorghum plants are especially sensitive to water deficiencies which may reduce the potential seed numbers. This period is considered the most critical period for grain production since seed numbers per plant account for $70 \%$ of the grain yield [22]. In 2002, the high rainfall amount occurred too late to have an effect on sorghum yield, and no response to row spacing or plant populations was noted. In 2003, rainfall for the critical time period (May) was below normal, and this resulted in the greatest yield production with the widest row spacing at the lowest plant populations for DK 54 .

3.3. Net Dollar Value per Hectare. Results for net dollar value were very similar to that found for yield (Table 3 ). In 2001, DK 54 planted on $51 \mathrm{~cm}$ centers at 185 to 198,000 plants/ha 
TABLE 3: Grain sorghum net dollar value per hectare minus seed costs as influenced by hybrid, row spacing, and seeding rate.

\begin{tabular}{|c|c|c|c|c|c|}
\hline \multirow{2}{*}{ Hybrid } & \multirow{2}{*}{ Row spacing $(\mathrm{cm})$} & \multirow{2}{*}{ Plant population (1000's/ha) } & \multicolumn{3}{|c|}{ Net value over seed costs $(\$ / h a)^{a}$} \\
\hline & & & 2001 & 2002 & 2003 \\
\hline \multirow{6}{*}{ Dekalb DK54 } & \multirow{3}{*}{51} & $148-160$ & 1319.43 & 652.35 & 602.58 \\
\hline & & $185-198$ & 1406.49 & 739.86 & 610.72 \\
\hline & & $222-235$ & 1200.41 & 618.65 & 646.73 \\
\hline & \multirow{3}{*}{102} & $148-160$ & 1126.92 & 642.00 & 742.35 \\
\hline & & $185-198$ & 1258.80 & 670.7 & 450.27 \\
\hline & & $222-235$ & 1250.46 & 634.67 & 556.73 \\
\hline \multirow{6}{*}{ Asgrow A571 } & \multirow{3}{*}{51} & $148-160$ & 1143.57 & 611.31 & 641.28 \\
\hline & & $185-198$ & 1305.84 & 761.10 & 441.69 \\
\hline & & $222-235$ & 1246.04 & 759.59 & 506.78 \\
\hline & \multirow{3}{*}{102} & $148-160$ & 1024.05 & 380.19 & 604.38 \\
\hline & & $185-198$ & 998.52 & 575.94 & 569.40 \\
\hline & & $222-235$ & 1015.46 & 554.75 & 501.02 \\
\hline LSD (0.05) & & & 220.22 & 260.91 & 151.27 \\
\hline
\end{tabular}

a Seed costs and grain sorghum prices were calculated based on April, 2012 prices (L. Falconer, personal communication). Seed costs were calculated at $\$ 6.60 / \mathrm{kg}$ (imidacloprid treated) while grain sorghum price was based on $\$ 9.00 / 45.4 \mathrm{~kg}$.

resulted in the greatest net return while A 571 grown on $102 \mathrm{~cm}$ centers at 185 to 198,000 plants/ha netted the least return (Table 3 ). In 2002, net dollar values were similar for all hybrids, row spacings, and plant populations with the exception of A 571 planted on $102 \mathrm{~cm}$ centers with a plant population of 148 to 160,000 plants/ha. In 2003, DK 54 planted on $102 \mathrm{~cm}$ centers at 148 to 160,000 plants/ha produced the greatest net return and this was greater than all plant populations of at least 185,000 plants/ha with the exception of DK 54 planted on $51 \mathrm{~cm}$ rows.

\section{Summary}

In the year when rainfall fell at the most opportune time, the narrow row spacings yields were slightly higher than the wide row spacings. However, in years when rainfall came at inopportune times, yields were variable. Results for the different populations were mixed. The lower plant populations did not always produce the greater yields especially in dryer years. Also, hybrid response was variable. Based on these results for this region, narrow rows may slightly help improve yields and profits. However, more research is needed to determine optimum plant populations, and also other hybrids need to be evaluated to determine if they may respond differently to narrow row plantings.

Responses to narrow row spacing in grain sorghum have been varied and inconsistent. Conley et al. [2] reported that grain yield response to row spacing was variable and dependent on environment. Welch et al. [24] reported that in the presence of adequate nitrogen, production of grain and residue increased with increasing populations. They concluded that under dryland conditions, optimum populations for both grain and residue production were between 99,000 and 148,000 plants/ha and that at populations of 99,000 plant/ha grain and residue yields in $40 \mathrm{~cm}$ rows equaled or exceeded those in $102 \mathrm{~cm}$ rows. In contrast, Karchi and
Rudich [25] in Israel reported that under dryland conditions, greater yields resulted from narrow rows combined with lower plant populations. They found that the greater grain yields were due primarily to increased number of heads per unit area rather than to changes in head weight. They also stated that heads per unit area and the number of kernels per head were largely free of environmental effects.

\section{Acknowledgments}

Kevin Brewer, Dwayne Drozd, A. J. Jaks, and Bill Klesel provided technical assistantce for this project. None of the authors have a direct financial relationship with any of commercial entities (Monsosem ATI, Inc.; SAS Institute, Inc.) mentioned in the paper.

\section{References}

[1] O. R. Jones and G. L. Johnson, "Row width and plant density effects on Texas High Plains sorghum," Journal Production Agriculture, vol. 4, pp. 613-621, 1991.

[2] S. P. Conley, W. G. Stevens, and D. D. Dunn, "Grain sorghum response to row spacing, plant density, and planter skips," Crop Management. In press.

[3] S. A. Staggenborg, D. L. Fjell, D. L. Devlin et al., "Grain sorghum response to row spacings and seeding rates in Kansas," Journal of Production Agriculture, vol. 12, no. 3, pp. 390-395, 1999.

[4] T. J. Gerik and C. L. Neely, "Plant density effects on main culm and tiller development of grain sorghum," Crop Science, vol. 27, pp. 1225-1230, 1987.

[5] T. A. Lafarge and G. L. Hammer, "Predicting plant leaf area production: shoot assimilate accumulation and partitioning, and leaf area ratio, are stable for a wide range of sorghum population densities," Field Crops Research, vol. 77, no. 2-3, pp. 137-151, 2002. 
[6] T. A. Lafarge and G. L. Hammer, "Tillering in grain sorghum over a wide range of population densities: modelling dynamics of tiller fertility," Annals of Botany, vol. 90, no. 1, pp. 99-110, 2002.

[7] Y. O. M'Khaitir and R. L. Vanderlip, "Grain sorghum and pearl millet response to date and rate of planting," Agronomy Journal, vol. 84, pp. 579-582, 1992.

[8] W. J. Grichar, "Planting date, cultivar, and seeding rate effects on soybean production along the Texas Gulf Coast," Crop Management. In press.

[9] R. H. Brown, E. R. Beaty, W. J. Ethredge, and D. D. Hays, "Influence of row width and plant population on yield of two varieties of corn (Zea mays L.)," Agronomy Journal, vol. 62, pp. 767-770, 1970.

[10] J. M. Fulton, "Relationships among soil moisture stress, plant populations, row spacing, and yield of corn," Canadian Journal Plant Science, vol. 50, pp. 31-38, 1970.

[11] B. A. Besler, W. J. Grichar, S. A. Senseman, R. G. Lemon, and T. A. Baughman, "Effects of row pattern configurations and reduced $(1 / 2 \mathrm{x})$ and full rates $(1 \mathrm{x})$ of imazapic and diclosulam for control of yellow nutsedge (Cyperus esculentus) in peanut," Weed Technology, vol. 22, no. 3, pp. 558-562, 2008.

[12] A. Limon-Ortega, S. C. Mason, and A. R. Martin, "Production practices improve grain sorghum and pearl millet competitiveness with weeds," Agronomy Journal, vol. 90, no. 2, pp. 227 232, 1998.

[13] H. H. Bryant, J. T. Touchton, and D. P. Moore, "Narrow rows and early planting produce top grain sorghum yields," Highlights Agriculture Research Alabama Agricultural Experiment Station, vol. 33, p. 5, 1986.

[14] W. J. Grichar, "Row spacing, plant populations, and cultivar effects on soybean production along the Texas Gulf Coast," Crop Management. In press.

[15] B. E. Tharp and J. T. Kells, "Effect of glufosinate-resistant corn (Zea mays) population and row spacing on light interception, corn yield, and common lambsquarters (Chenopodium album) growth," Weed Technology, vol. 15, pp. 413-418, 2001.

[16] K. D. Thelen, "Interaction between row spacing and yield: why it works10," Crop Management. In press.

[17] F. H. Andrade, P. Calviño, A. Cirilo, and P. Barbieri, "Yield responses to narrow rows depend on increased radiation interception," Agronomy Journal, vol. 94, no. 5, pp. 975-980, 2002.

[18] W. C. Johnson, E. P. Prostko, and B. G. Mullinix, "Improving the management of dicot weeds in peanut with narrow row spacings and residual herbicides," Agronomy Journal, vol. 97, no. 1, pp. 85-88, 2005.

[19] J. R. Teasdale, "Influence of narrow row/high population corn (Zea mays) on weed control and light transmittance," Weed Technology, vol. 9, no. 1, pp. 113-118, 1995.

[20] M. J. Kasperbauer and D. L. Karlen, "Plant spacing and reflected far-red light effects on phytochrome-regulated photosynthate allocation in corn seedlings," Crop Science, vol. 34, no. 6, pp. 1564-1569, 1994.

[21] D. G. Bullock, R. L. Nielsen, and W. E. Nyquist, "A growth analysis comparison of corn growth in conventional and equidistant plant spacingg," Crop Science, vol. 28, pp. 254-258, 1988.

[22] J. Kelley, "Chapter 1: Growth and development," Grain Sorghum Handbook, MP 297, 2012, http://www.uaex.edu/Other _ Areas/publications/PDF/MP297/1_growth_development.pdf.

[23] National Climatic Data Center, http://www.ncdc.noaa.gov/oa/ ncdc.html.

[24] N. H. Welch, E. Burnett, and H. V. Eck, "Effect of row spacing, plant population, and nitrogen fertilization on dryland grain sorghum production," Agronomy Journal, vol. 58, pp. 160-163, 1966.

[25] Z. Karchi and Y. Rudich, "Effects of row width and seedling spacing on yield and its components in grain sorghum grown under dryland conditions," Agronomy Journal, vol. 58, pp. 602-604, 1966. 


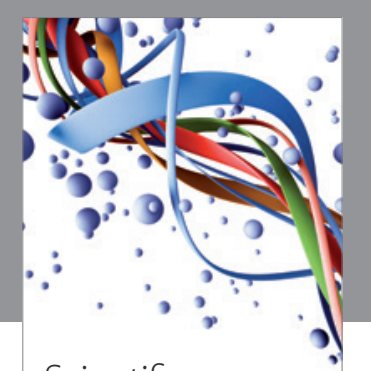

Scientifica
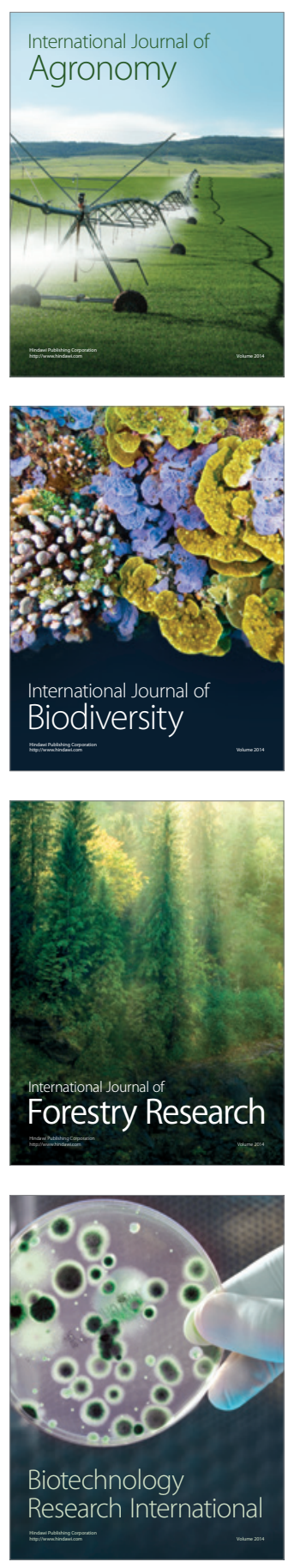
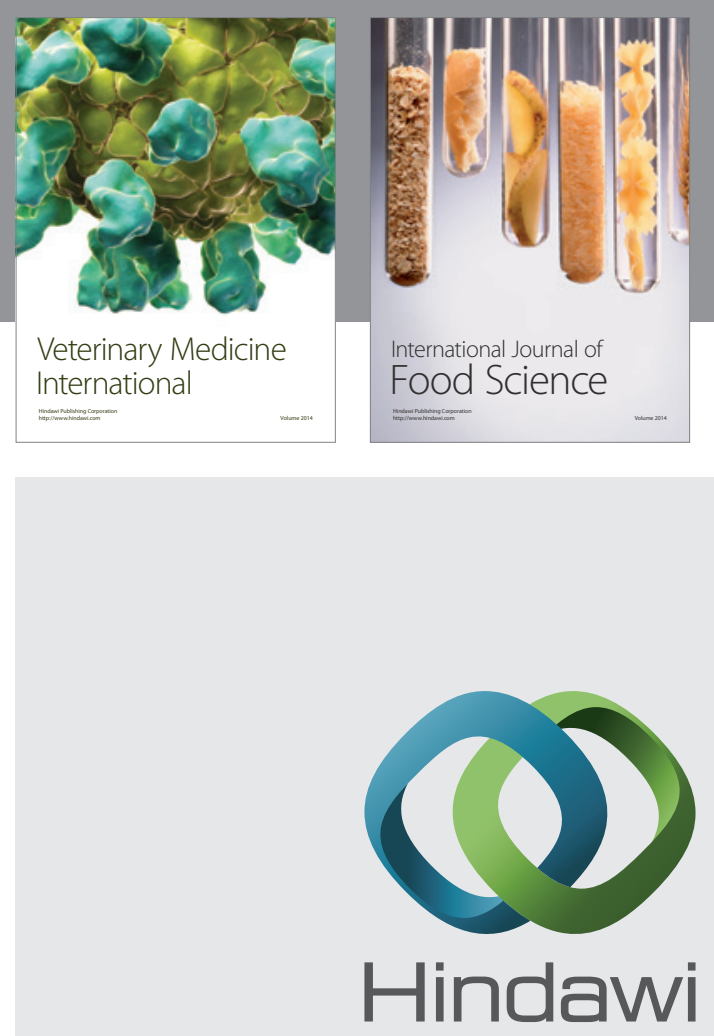

Submit your manuscripts at

http://www.hindawi.com
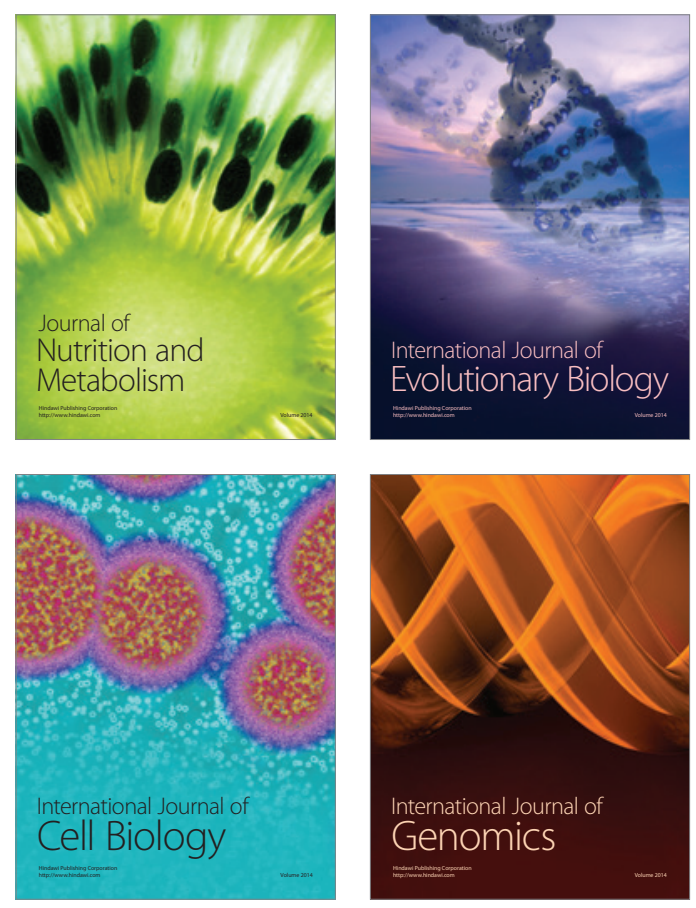
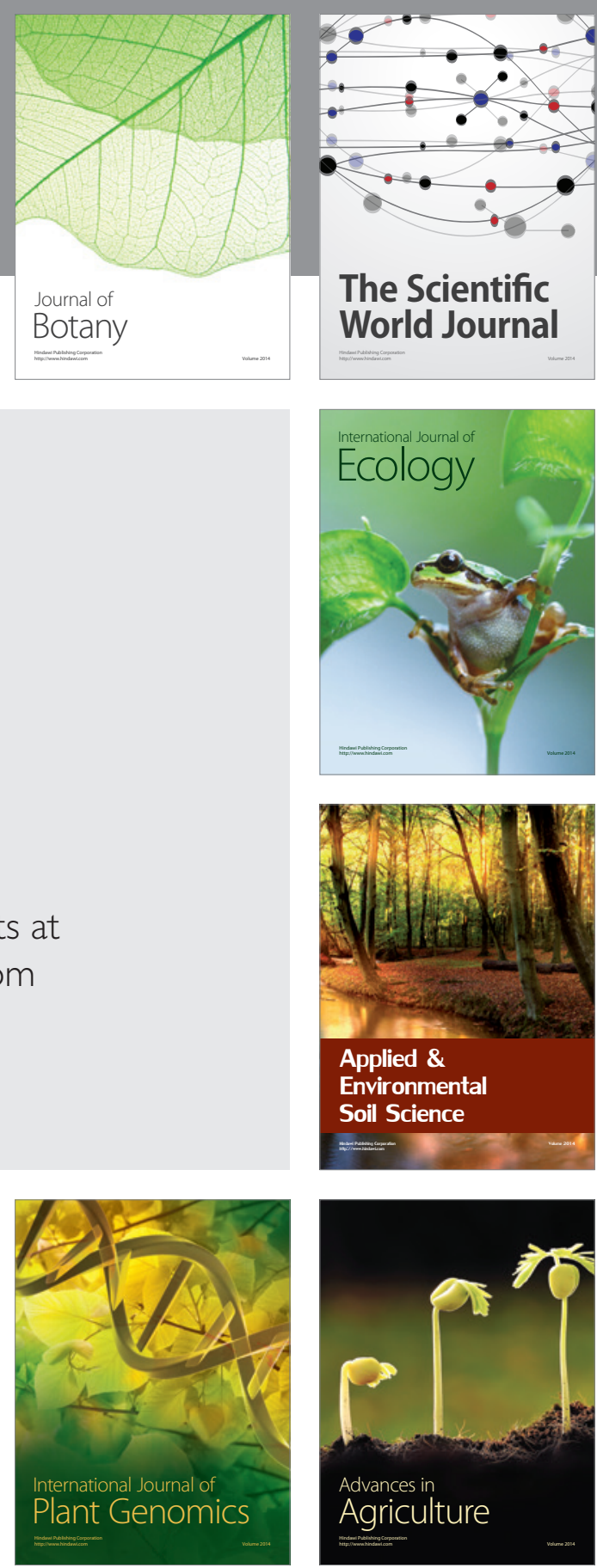

The Scientific World Journal
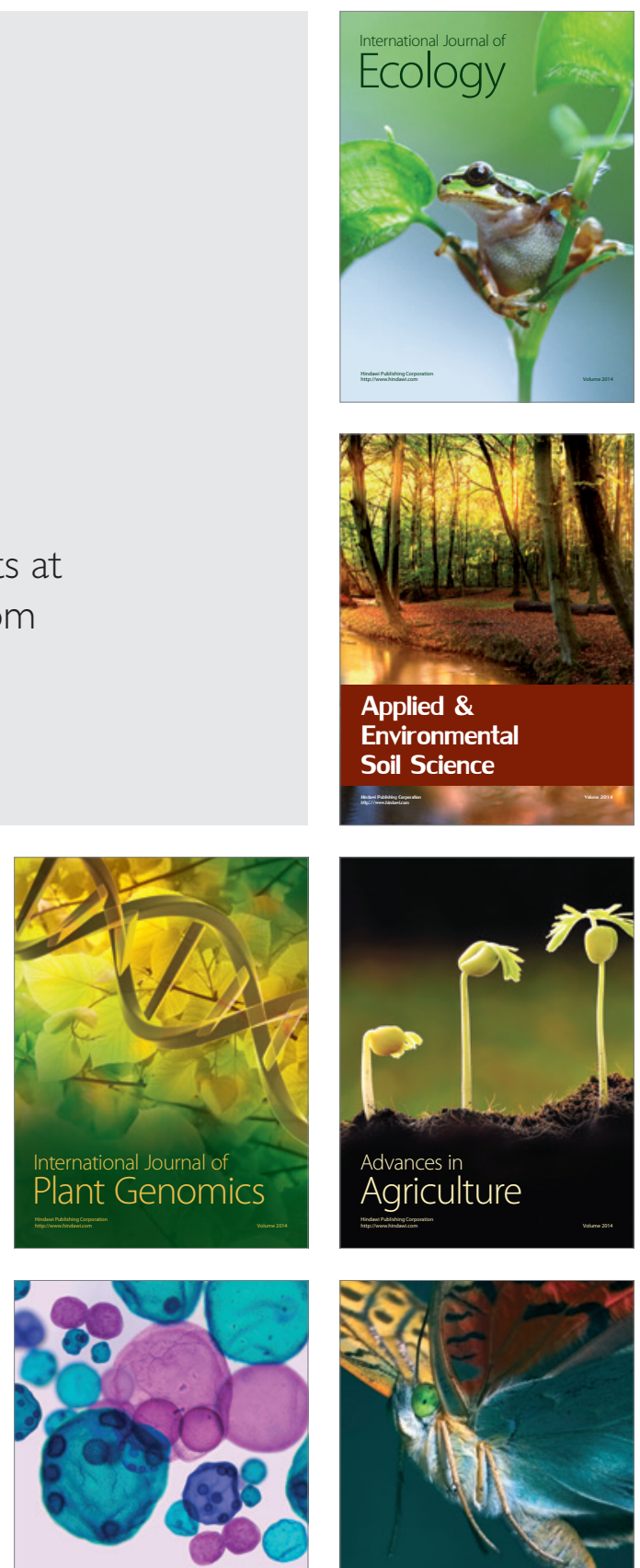

International Journal of Microbiology

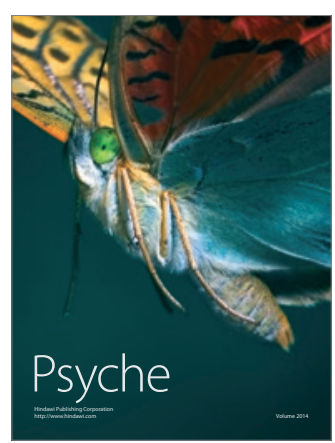

